\title{
Esther Benbassa (dir.), Salonique. Ville juive, ville ottomane, ville grecque
}

Paris, CNRS Éditions, coll. « Les Cahiers Alberto-Benveniste », 2014, 194

p.

\section{Michael Löwy}

\section{(2) OpenEdition}

\section{Journals}

Édition électronique

URL : http://journals.openedition.org/assr/26306

DOI : $10.4000 /$ assr.26306

ISSN : $1777-5825$

Éditeur

Éditions de l'EHESS

Édition imprimée

Date de publication : 31 décembre 2014

Pagination : 126

ISBN : 978-2-7132-2467-6

ISSN : 0335-5985

Référence électronique

Michael Löwy, «Esther Benbassa (dir.), Salonique. Ville juive, ville ottomane, ville grecque ", Archives de sciences sociales des religions [En ligne], 168 | 2014, mis en ligne le 02 avril 2015, consulté le 22 septembre 2020. URL : http://journals.openedition.org/assr/26306 ; DOI : https://doi.org/10.4000/ assr.26306

Ce document a été généré automatiquement le 22 septembre 2020

(C) Archives de sciences sociales des religions 


\section{Esther Benbassa (dir.), Salonique. Ville juive, ville ottomane, ville grecque}

Paris, CNRS Éditions, coll. « Les Cahiers Alberto-Benveniste », 2014, 194

p.

Michael Löwy

\section{RÉFÉRENCE}

Esther Benbassa (dir.), Salonique. Ville juive, ville ottomane, ville grecque, Paris, CNRS Éditions, coll. «Les Cahiers Alberto-Benveniste », 2014, 194 p. 
1 Cet intéressant recueil de textes, publié dans la collection « Les Cahiers AlbertoBenveniste " (consacrés au Judaïsme sépharade) rassemble les contributions d'un colloque international organisé en janvier 2013 à l'École normale supérieure (Ulm). Il confronte les différentes expériences de vie culturelle, politique et religieuse à Salonique, au cours du $x^{e}$ siècle.

2 Comme le rappelle Aron Rodrigue dans sa préface, Salonique était devenue, après l'expulsion des Juifs d'Espagne à la fin du $\mathrm{XV}^{\mathrm{e}}$ siècle, la ville judéo-espagnole par excellence, et même, au cours du siècle suivant, la ville avec la plus grande population juive en Europe. Vers la fin $d u$

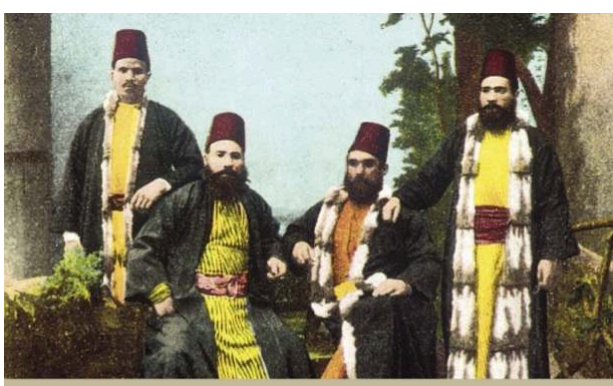

Sous la direction de

Esther Benbassa

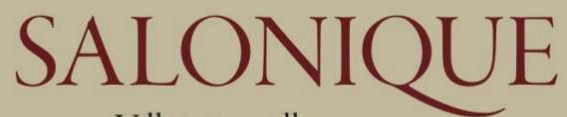

Ville juive, ville ottomane, ville grecque

CNRS EDITIONS $\mathrm{XIX}^{\mathrm{e}}$ siècle, les Juifs étaient encore majoritaires dans cette "Jérusalem des Balkans ", qui faisait partie de l'Empire ottoman, et qui comportait aussi des populations turques, bulgares et grecques. Avec l'incorporation de la ville à l'État grec en 1913, commence un processus de "desottomanisation », qui aboutit en 1923 à l'ainsi nommé « échange de populations » avec la Turquie, avec le départ (volontaire ou contraint) de la population musulmane et l'arrivée des réfugiés grecs (Meropi Anastassiadou).

3 Les Juifs jouaient un rôle important dans la vie économique (Dilek Akyalçin Kaya), mondaine (Hélène Guillon) et politique de la ville. Comme le montre Esther Benbassa dans sa remarquable contribution, l'activité sioniste et socialiste des Juifs de Salonique, initiée encore à l'époque ottomane, va s'intensifier dans l'État (relativement démocratique) grec, avant l'établissement de la dictature du général Metaxas en 1936. Tandis que les travailleurs juifs de la banlieue optent pour les socialistes et les communistes, la bourgeoisie occidentalisée soutient le «modernisateur» Venizelos, tandis que les sionistes sont du côté des conservateurs et monarchistes. La particularité du sionisme de Salonique c'est la faiblesse du courant socialiste ; prédomine le sionisme religieux (Mizrachi) qui va fusionner, entre 1924 et 1933, avec la droite nationaliste (les sionistes dits "révisionnistes »). L'antisémitisme, étroitement lié à l'anticommunisme («Juif» et "communiste » sont associés) conduira, en 1931, à un pogrom fasciste contre les habitants juifs de la banlieue. Plus la position des Juifs se fragilise dans la ville, plus se développe une historiographie juive- Isaac Emmanuel, Noseph Nehama, Michael Molho - célébrant le passé glorieux de la «Jérusalem des Balkans » (Devin E. Naar).

4 La fin tragique de cette histoire est connue : en 1943, sous l'occupation nazie, et avec la complicité active d'autorités grecques locales, la presque totalité des Juifs de Salonique fut déportée à Auschwitz. Sur environ 56000 personnes en 1940, seuls 1950 étaient encore vivants en $1945 .$. Il s'agit d'un chapitre noir de l'histoire contemporaine, bien absent des livres d'histoire et des colloques universitaires grecs (Rena Molho). 
5 Deux moments importants de l'histoire des Juifs de Salonique me semblent manquer dans ce recueil : 1) la Fédération socialiste ouvrière fondée par Avraham Benarroya en 1909, à prédominance juive, mais associant des travailleurs turcs, grecs et bulgares, qui va jouer un rôle important dans les origines du mouvement ouvrier (socialiste et communiste) grec ; 2) la participation des Juifs dans l'EAM, le principal mouvement de résistance grec (dirigé par une coalition de gauche, sous l'hégémonie communiste), pendant l'occupation nazie de la Grèce (1940-1944). Une récente exposition dans le Musée Juif d'Athènes a été consacrée à cette histoire, accompagnée de la publication d'une importante documentation.

6 Cela dit, ce petit livre n'avait pas vocation à l'exhaustivité, et il apporte une contribution précieuse à la connaissance d'une ville singulière dans l'histoire des Balkans. 